\title{
Sales of residential properties illustrated with the City of Kalisz
}

\author{
Izabela Rącka \\ Stanistaw Wojciechowski Higher Vocational State School \\ in Kalisz, Poland \\ isska@interia.pl
}

\begin{abstract}
Properties are one of the most rapidly developing segments of the Polish economy. The development of the property market involves not only transformations of all of its operating aspects, but also awareness of importance of property market surveys, which are a useful source of information for investors. This analysis focuses on fluctuation of transactional prices of residential properties in Kalisz in 2003-2012. An attempt has been made to identify factors affecting a property price. The analysis leads to a few significant findings. When compared to the domestic property market and parallel local markets, sales are low.

An analysis of dependences between the price and the land area has led to a conclusion that the correlation dependence is of positive nature. Upon analyzing time tendency of the transactional prices, an average monthly price growth has been identified. The local market demonstrates tendencies reflecting the country-wide phenomena.
\end{abstract}

Received: July, 2013

1st Revision: September, 2013

Accepted:

November, 2013 $10.14254 / 2071-$
$8330.2013 / 6-2 / 12$

Keywords: properties, market analysis, transactions, residential properties, property price.

JEL classification: R31.

\section{INTRODUCTION}

The main objective is to identify the factors affecting the local housing markets (especially a property price) and the direction of changes on the example of the city of Kalisz. The analysis focuses on fluctuation of transactional prices of residential properties (only market transactions) in Kalisz in 2003-2012. The major sources of references were publications, analysis and Central Office of Statistics data. The first section contains theoretical information and Central Office of Statistics data. The second section (analysis) contains research findings (empirical).

\section{DEVELOPMENT OF THE DOMESTIC PROPERTY MARKET}

As a result of World War 2 acts over 2 million apartments were destroyed in Poland. Reconstruction of the residential substance was hard; by 1949 nearly 600,000 rooms were renovated and approximately 
300,000 were built. In December 1946 a decree of public management of residence and rental"1 was passed which entitled housing authorities (presidium of the town or municipal national council) to allocate occupants to private flats in the biggest Polish towns Warsaw, Lodz, Gdansk, Lublin, Cracow, Katowice and Poznan. In 1951 it was extended onto the whole territory of Poland. In the times of the Polish People's Republic, as a result of inefficient communist economy, application of obsolete building technologies and the fact that the residential building industry - unlike heavy industry - was not a priority sector of the economy. Flats were in short supply. In the second half of 1960's development of residential building industry in Poland clearly gathered speed. However, flats were built with savings in mind; they were small and short, kitchens were dark. The 1970's were a peak of the Polish production potentials in the residential building market driven by changes in the then flat building policy and application of a new, very efficient technology - large-panel blocks of flats. After some time it turned out that the so-called "factories of buildings" manufacturing pre-fabricated large-size components to build residential buildings were not modernized and the "large panel" was frequently defective. The residential building policy was quantity-oriented and the quality of workmanship was ignored. In the 1980's the scale of national building investments decreased while unsatisfied housing needs of Poles grew. In 1989 the ratio of flats per 1000 people was only 289.

The property market in Poland has been in existence for slightly over 20 years and is not a well-developed market. The initial impact of political and economic transformations upon the emerging market was not positive; the number of flats commissioned during the last two decades is comparable (9\% smaller) to that during the Polish peak of the 1970's (Nykiel, 2008). At the end of 2010 in Poland there were over 13.4 million flats (285 flats per 1000 people) according to the National Census in 2011. On 31 March 2011 the flat resources in Poland amounted to 13.7 million, half of which were located in blocks of flats (56.3\%), single-family homes were $42.4 \%$ and a small number of flats were located in non-residential buildings $(0.4 \%)$ or in collective living objects $(0.1 \%)^{2}$.

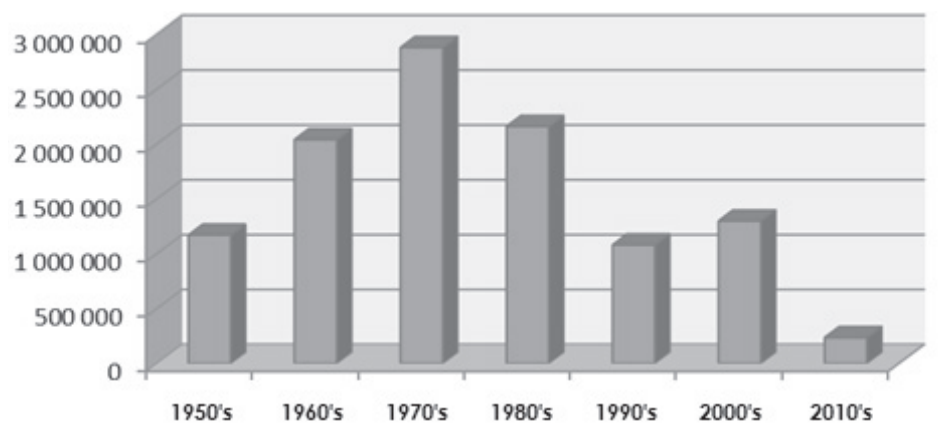

Chart 1. Number of flats commissioned in Poland in 1950-2012

Source: self-study based on L. Nykiel, Residential market in Poland, Bulletin 25/2008, Mortgage Credit Foundation, Warsaw 2008, p.69 and Central Office of Statistics (GUS) data.

The Polish residential building industry experienced the most serious problems in 1990's when having commissioned cooperative flats whose construction had begun before the political transformation, the number

Decree of "public management of residence and rental" Journal 1946 No 4 sec. 27

2 Results of 2011 National Census, Basic information about demographic and social condition of the Polish population and housing resources, analysis prepared for the Demographic Congress on 22-23 March 2012, GUS, Warsaw, March 2012 
of commissioned flats equalled that from forty years before. Limited public support, hyperinflation, and high interest rates - these are only a few factors which slowed down building development in the said period.

It is noteworthy though that in the 1990's activity of individual investors was stable (around 35,000 flats annually).

Activity of investors in the Polish housing market in 1991-2012 is shown in Chart 2.

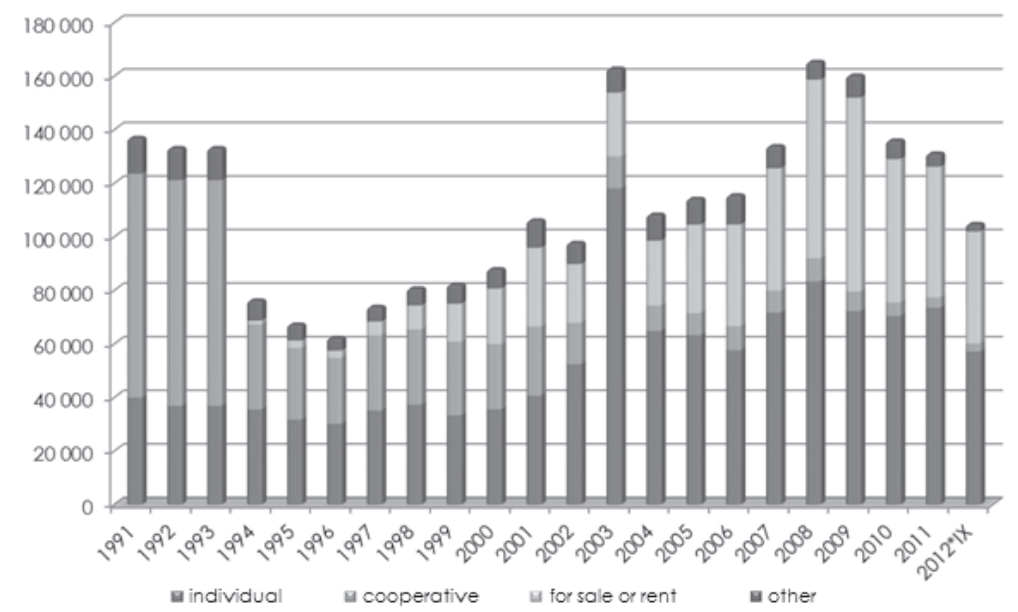

Chart 2. Number of flats commissioned in Poland in 1991-2012

Source: self-study based on GUS data

The analysis of the property market in Poland between mid 1990's and 2008 shows a growing tendency of the residential building industry. A regular growth of commissioned flats ceased soon after the so-called "price boom" in the Polish property market followed by a collapse of the housing market (2003 witnessed a rapid growth of commissioned flats built by individual investors most likely resulting from a failure to register living houses built in previous years and triggered by announcements of thorough building inspections and high penalties).

Until 2008 the overall value of completed transactions rose. Chart 3 shows the above dependence. It also depicts a drop in transactions in 2008 vs. 2007 by almost $10 \%$ while the value of transactions grew by $7 \%$ (9\% within town borders). In 2009 further reduction of property sales in Poland took place. 


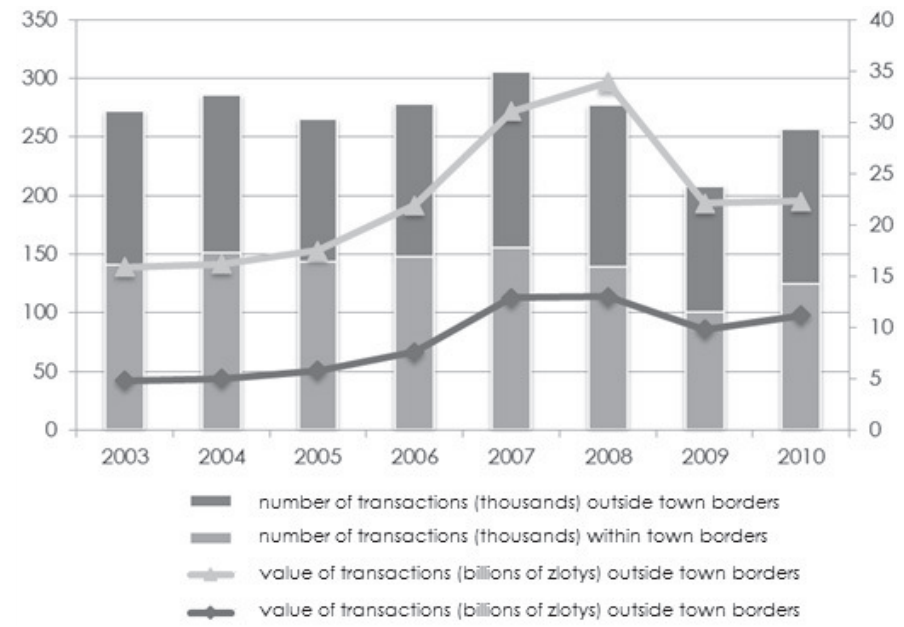

Chart 3. Number and value of transactions in the property market in Poland in 2003-2011 (within and outside town borders) in billions of zlotys.

Source: self-study based on property purchase/sale transactions in 2008, Institute of Urban Development, Cracow, September 2009 and Property sales in 2011. Statistical data and studies,

Central Office of Statistics, Warsaw 2012.

The increased value of transactions in recent years in Poland demonstrates several particular tendencies: proportions between the number of market and non-market transactions change (the share of market transactions is growing), the number of transactions involving residential buildings and flats is getting smaller while interest in other kinds of properties (including but not limited to commercial and industrial properties $)^{3}$ is rising. Development of the Polish property market is also witnessing a decline of transactions where the State Treasury or a municipality is a party whereas participation of other entities in the property sales is becoming larger. Transformations are present in all aspects of the property market such as establishing and recently adjusting the law to the Community requirements, establishing principles of property sales or entities operating in the market. Therefore, it is essential awareness of importance of property market surveys become higher as they may be a significant source of information for investors.

The large majority of property transactions involve residential properties. In order to demonstrate dependences present in the local property market as compared to the country-wide market, fluctuation of transactional prices of residential properties in 2003-2012 in Kalisz has been analyzed.

\section{PROPERTY MARKET IN KALISZ}

Kalisz is a county town, the second largest town in Wielkopolska, covering almost $70 \mathrm{~km}^{2}$ and over 101,000 inhabitants $^{4}$. The town is characterized by a developed urban infrastructure and is a centre of textile,

\footnotetext{
3 comp. Purchase/sale property transactions in 2007, Central Office of Statistics, Warsaw, September 2008, p. 20-22 and Property sales in 2010, Central Office of Statistics, Warsaw, 2011

4101396 , status as on 31.12.2012.
} 
food and aircraft industries. The unemployment rate is lower than the national average and amounts to 7.6\%. Kalisz has almost 12,000 registered business entities, including 130 foreign ones, which are the largest employers in the town. The property market in Kalisz is an emerging one especially as regards commercial areas. Residential areas are developed to a large extent; new plots are formed by splitting large plots in non-urbanized areas. Multi-family housing sector in Kalisz has been rapidly developing since 1998; the investors include Kalisz developers, housing cooperatives and individual investors. In recent years single-family homes and blocks of flats tend to concentrate on the outskirts and in suburban areas. Since a few years ago a tendency has shown to change the function of properties located in the town centre - from residential to services. However, progress in this field is insufficient.

An equally important aspect of the development of the local property market is local site development plans to be developed and adopted by the Town Council in Kalisz. In recent years development plans have been created for both residential and commercial areas. As a result, interest in those lands among domestic and foreign investors is growing. The local plans designating lands for single-family homes are accompanied by the town's infrastructure investments, in particular, in roads and sewage systems (a sewage network of over $95 \mathrm{~km}$ has been built as well as $52.9 \mathrm{~km}$ of roads in Kalisz since 2005 which is $31 \%$ increase in $2005-2011)^{5}$.

\section{ANALYSIS OF THE RESIDENTIAL PROPERTY MARKET IN KALISZ IN 2003-2012}

The analysis involved residential property transactions (undeveloped lands, houses) in Kalisz from 01.01.2003 (lands) and from 01.01.2006 (houses) till 31.12.2012.

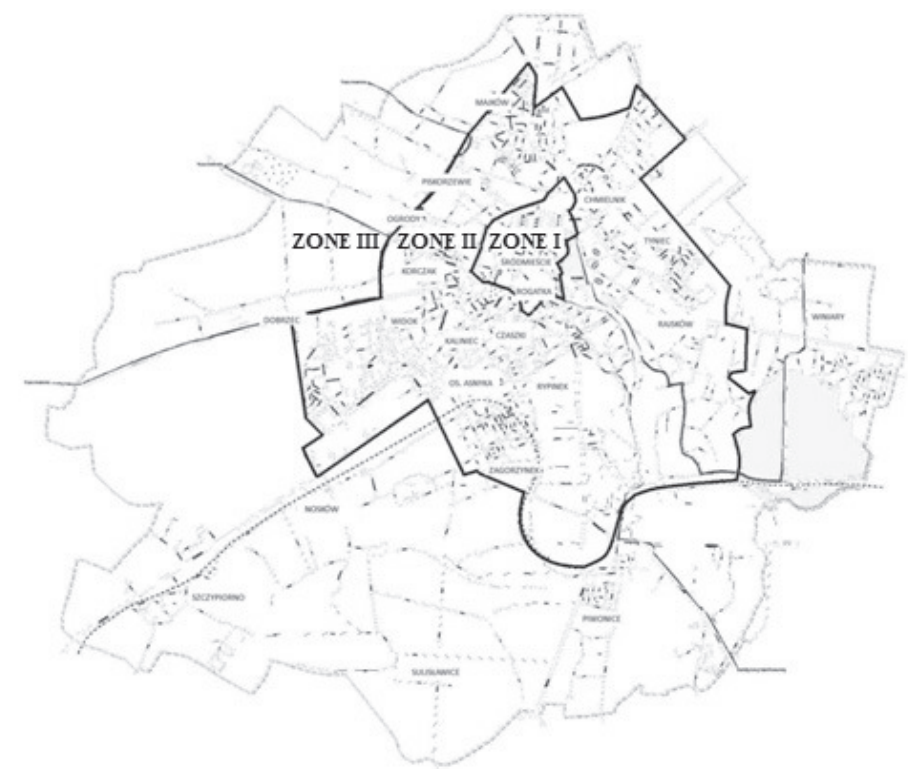

Figure 1. Precincts and zones of attraction in Kalisz Source: self-study.

5 Data by the Municipal Road Authority in Kalisz 


\section{ANALYSIS OF THE MARKET OF UNDEVELOPED PROPERTIES DESIGNATED FOR RESIDENTIAL BUILDINGS IN KALISZ IN 2003-2012}

Table 1

Number of transactions - undeveloped land properties intended for single-family homes in Kalisz in 2003-2012 divided into zones

\begin{tabular}{|c|c|c|c|c|c|c|c|c|c|c|c|}
\hline Zone/Year & 2003 & 2004 & 2005 & 2006 & 2007 & 2008 & 2009 & 2010 & 2011 & 2012 & $2003-2012$ \\
\hline 2 & 42 & 39 & 11 & 19 & 41 & 40 & 44 & 23 & 17 & 18 & 294 \\
\hline 3 & 12 & 35 & 15 & 26 & 31 & 49 & 29 & 64 & 43 & 19 & 323 \\
\hline Kalisz & 54 & 74 & 26 & 45 & 72 & 89 & 73 & 87 & 60 & 37 & 617 \\
\hline
\end{tabular}

Source: self-study

Most building lands were sold in precincts of single-family home nature - the second most attractive zone (in recent years a growing tendency is seen in transaction on the town outskirts), the fewest in precincts other than single-family building estates. The town centre (compact, multi-family centre building development) had no transactions involving single-family lands. In 2003-2008 the number of transactions grew, after 2010 it is clearly declining.

Most plots sold (almost half) had an area between $500 \mathrm{~m}^{2}$ and $1000 \mathrm{~m}^{2}$, every fourth plot was less than $500 \mathrm{~m}^{2}$. The areas of single-family housing plots up to $1000 \mathrm{~m}^{2}$ are characteristic of properties situated in the urban areas. This dependence is visible in the town's division into zones of attraction: in zone two one of three plots sold has an area above $1000 \mathrm{~m}^{2}$, zone three has fewer plots of area up to $500 \mathrm{~m}^{2}$; bigger plots prevail offering more space to arrange a garden.

The most frequent sellers are natural persons. Almost all transactions concerned a title to land; in the last decade sales involving perpetual lease of land in Poland are going down; in 2010 those transactions made only $0.039 \%$ of total land sold and $0.001 \%$ of housing land sold, in $2011-0.017$ of total land sold whereas there sales of perpetual lease of housing land were none. The situation of undeveloped residential properties in Kalisz market is similar.

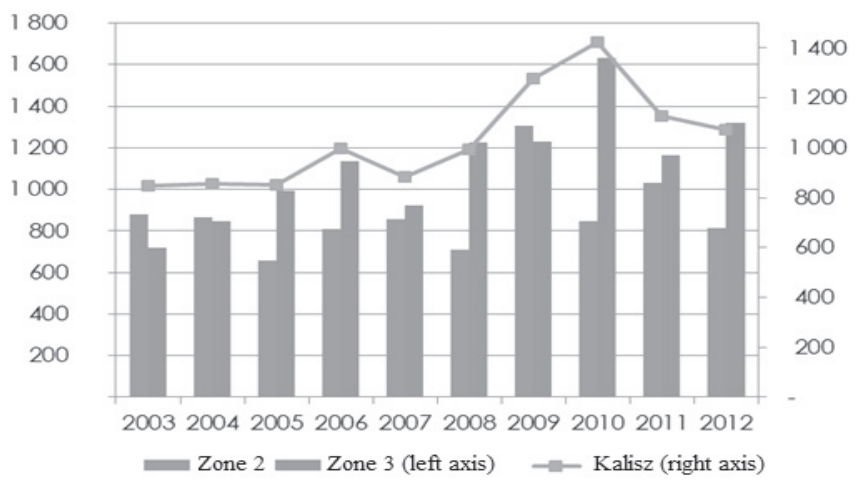

Chart 4. Average area [m2] of undeveloped plots intended for single-family homes sold in Kalisz in 2003-2012 divided into zones

Source: self-study. 
The average size of a plot sold in 2003-2012 in Kalisz was $1058 \mathrm{~m} 2$. The average diversity of the analyzed pool of lands for their area is $983 \mathrm{~m} 2$. The differences are clear between the average size of the plot in the second and third zones of attraction, where 294 and 323 transaction were concluded respectively. The average size of the plot in the third zone of attraction was bigger than that in zone two by $33 \%$.

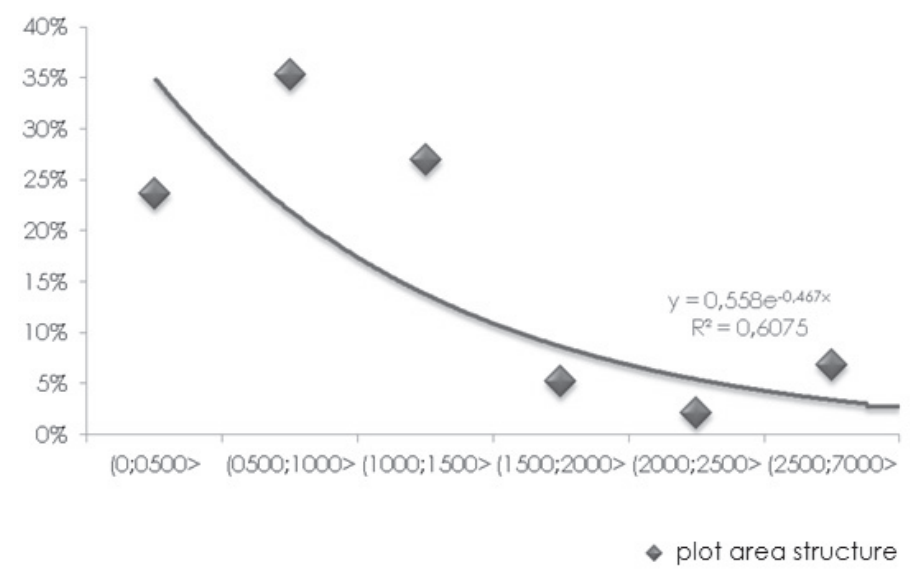

Chart 5. Plot area structure

Source: self-study.

The land distribution if asymmetrical and right hand-sided though very poor with the asymmetry ratio of As=0,06: the average plot area $\left(1058 \mathrm{~m}^{2}\right)$ is bigger than the most common one in the analyzed pool $\left(1000 \mathrm{~m}^{2}\right)$.

Comparison of the data throughout the analyzed period requires their standardization. Therefore, an attempt has been made to identify the development tendency of transactional prices in the residential property market - slow, regular and systematic changes of a specific phenomenon observed in a sufficiently long span of time and being a result of key causes. In order to identify a tendency a long time should be used; the tendency function has been calculated for an average price of a square metre for plots sold in monthly intervals in 2003-2012. To identify the trend's function an analytical method was employed which matches a specific mathematical function to the whole time span. Based on unit transactional prices used during the analysis, the trend's function formula has been established. The calculated trend's function of the second kind takes form of $\hat{y}=0,58 x+78,29$. It means that the average price of one square metre rose month by month by PLN 0.58 whereas its theoretical value in the period immediately preceding the analysis that is in December 2002 amounted to PLN 78.29. It was found out that the average increase in prices of undeveloped plots intended for single-family homes in Kalisz property market in $2003-2012$ was $0.74 \%$ monthly.

From the very beginning of the analyzed period the average price of one square metre was characterized by a growing tendency with a slight drop in 2011. In the last analyzed year the average price doubled when compared to 2003. 


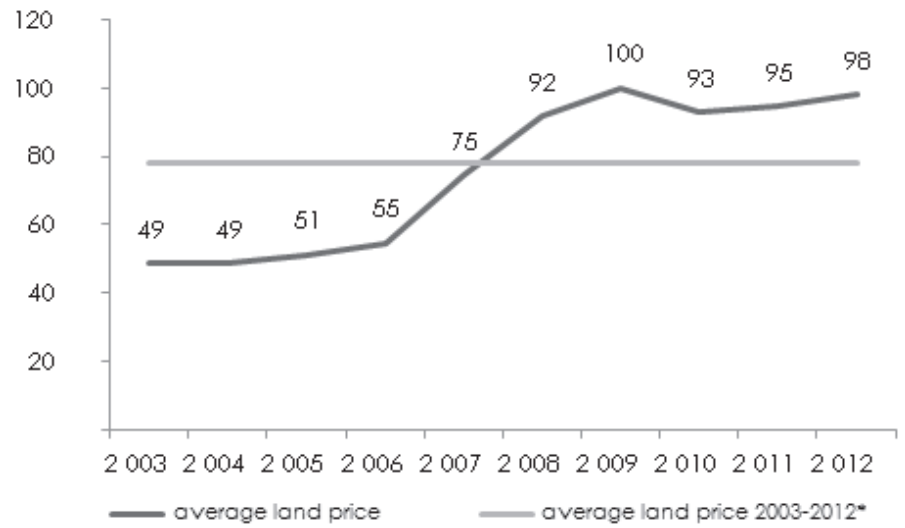

Chart 6. Average land price [PLN/m2]

Source: self-study

Average prices for individual area ranges are shown in Table 2.

Table 2

Average land price [PLN/m2] depending on the area in Kalisz in 2003-2012

\begin{tabular}{|c|c|c|c|c|c|c|c|c|c|c|c|}
\hline $\begin{array}{c}\text { Area/ } \\
\text { Year 20.. }\end{array}$ & 03 & 04 & 05 & 06 & 07 & 08 & 09 & 10 & 11 & 12 & $03-12$ \\
\hline$(0 ; 0500>$ & 66 & 61 & 82 & 93 & 80 & 109 & 139 & 127 & 93 & 74 & 94 \\
\hline$(0500 ; 1000>$ & 46 & 45 & 42 & 56 & 76 & 104 & 115 & 115 & 108 & 124 & 86 \\
\hline$(1000 ; 1500>$ & 32 & 42 & 42 & 40 & 66 & 81 & 74 & 75 & 74 & 79 & 65 \\
\hline$(1500 ; 2000>$ & 31 & 42 & 50 & 42 & 65 & 34 & 47 & 74 & 184 & 87 & 66 \\
\hline$(2000 ; 2500>$ & 24 & & 25 & 28 & 20 & 44 & 30 & 39 & 93 & 42 & 43 \\
\hline$(2500 ; 7000>$ & 58 & 24 & & 69 & 103 & 54 & 79 & 42 & 80 & 79 & 60 \\
\hline Suma końcowa & 49 & 49 & 51 & 55 & 75 & 92 & 100 & 93 & 95 & 98 & 78 \\
\hline
\end{tabular}

Source: self-study

The average price of undeveloped plots intended for single-family homes in Kalisz in 2003-2012 was $78 \mathrm{PLN} / \mathrm{m}^{2}$ (taking into account the time tendency: $98 \mathrm{PLN} / \mathrm{m}^{2}$ ). In the individual area ranges, the highest average unit price was observed for plots with area under $500 \mathrm{~m}^{2}\left(94 \mathrm{PLN} / \mathrm{m}^{2}\right)$.

A reduction in land unit prices was observed as the area increased: plots over $500 \mathrm{~m}^{2}$ to $1000 \mathrm{~m}^{2}$ inclusive were sold on average at a price $9 \%$ lower than the price of smallest area plots, among plots over $1000 \mathrm{~m}^{2}$ and not more than $1500 \mathrm{~m}^{2}$ the average selling price was at $69 \%$ of that of the smallest area plots.

The selling price of one square metre deviates by PLN 49 from the average. The distribution of the plot's average unit price as asymmetrical and right hand-sided - the average price of one square metre is higher than the most common price of one square metre while this asymmetry is fairly strong (asymmetry ratio As $=0.58$ ).

Between transactional prices and area of the plots sold in Kalisz in 2003-2012 is a positive linear correlation (average dependence, Pearson's linear correlation coefficient is 0.47 ). 


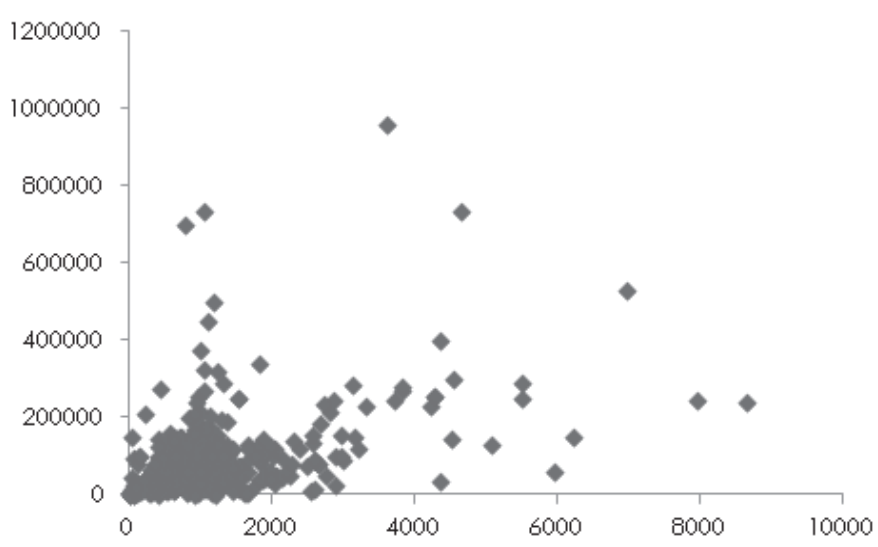

Chart 7. Dependence between the price $[\mathrm{PLN}]$ and the plot area $[\mathrm{m} 2]$ Source: self-study

The determination coefficient during the analysis period was 0.22 , which means that only $22 \%$ of transactional price variances were justified by different land areas. Therefore, a conclusion arises that the land price is also affected by other factors (Racka, 2009).

\section{ANALYSIS OF THE MARKET OF PROPERTIES BUILT UP WITH RESIDENTIAL BUILDINGS IN KALISZ IN 2006-2012}

The number of data describing homes sold in terms of characteristics included in the analysis looks as follows in respective years.

Table 3

Number of transactions - properties built up with residential buildings in Kalisz in 2006-2012 divided into zones

\begin{tabular}{|c|c|c|c|c|c|c|c|c|}
\hline Zone/Year & 2006 & 2007 & 2008 & 2009 & 2010 & 2011 & 2012 & $2006-2012$ \\
\hline 1 & 2 & 0 & 0 & 0 & 1 & 1 & 2 & 6 \\
\hline 2 & 53 & 21 & 24 & 18 & 20 & 25 & 15 & 176 \\
\hline 3 & 28 & 10 & 10 & 21 & 13 & 16 & 12 & 110 \\
\hline Kalisz & 83 & 31 & 34 & 39 & 34 & 42 & 29 & 292 \\
\hline
\end{tabular}

Source: self-study

Most homes were sold in single-family residential precincts; the fewest in multi-family precincts. Every third home was located on the town outskirts, $5 \%$ in the centre zone, other in intermediate zones. In 2006 a record number of transactions were concluded regarding land properties built up with single-family homes which was to a large extent caused by expiring building relief (for those who in 2002-2006 incurred a building credit or a credit to repay a building credit for building or purchasing a new residential building or a residential 
premises; deductions can be made by the credit repayment date not later, however, than by 31.12.2027). In the following year the number of transactions dropped by two thirds only to slowly increase in the following year.

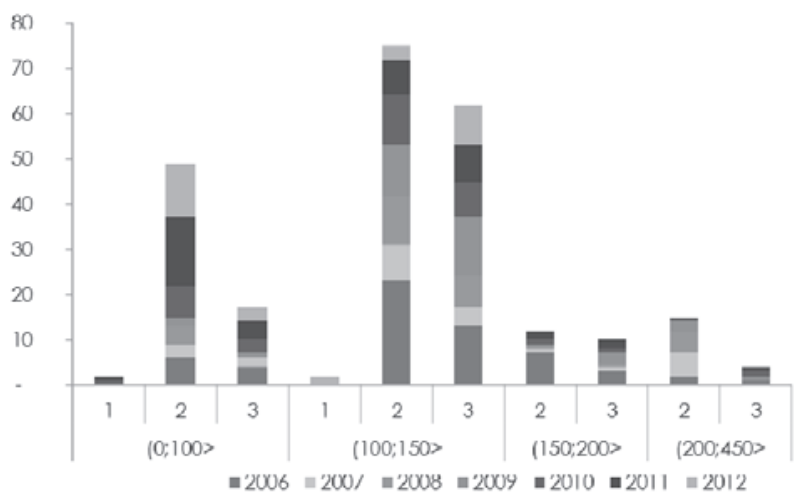

Chart 8. Number of transactions - properties built up with residential buildings in Kalisz in 2006-2012 divided by area and zone of attraction

Source: self-study.

The area of analyzed homes was divided into the above-mentioned ranges. Every second home had an area from $100 \mathrm{~m}^{2}$ to $150 \mathrm{~m}^{2}$, every third home was small (up to $100 \mathrm{~m}^{2}$ ), and every fifth had an area over $150 \mathrm{~m}^{2}$. Most frequently sold single-family homes had an area of $134 \mathrm{~m}^{2}$; the average variance of the analyzed pool for the area is $69 \mathrm{~m}^{2}$.

The most frequent seller is a natural person. The City of Kalisz is hardly ever a seller, it is a buyer in most cases when designating a property to a public purpose.

An average size of a home sold in 2006-2012 in Kalisz was $149 \mathrm{~m}^{2}$, and throughout the analysis period it looked as follows:

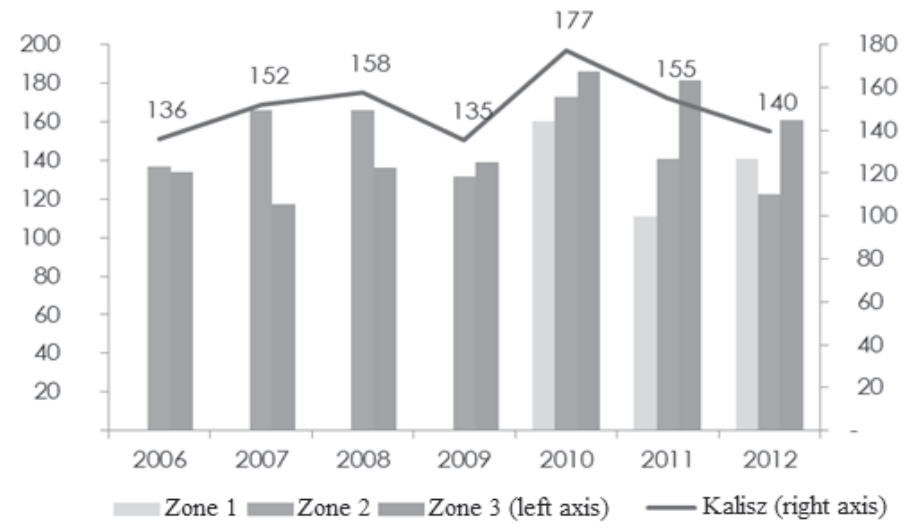

Chart 9. Average area of residential buildings in Kalisz in 2006-2012 divided by zone of attraction Source: self-study. 
Average areas of residential buildings are similar for individual zones of attraction. Interesting results arise from analyzing areas of built-up plots: in the second zone plot areas are smaller than those of properties located in the town outskirts. The differences vary from $30 \%$ to $70 \%$. This is an acknowledgment of the thesis set forth when analyzing undeveloped plots - building plots located farther from the town centre are characterized by bigger areas.

The calculated trend's function for properties built up with residential buildings in monthly intervals of 2006-2012 takes form of $\hat{y}=13,4 x+2256$. The price of one square metre grew by PLN 13.40 monthly and its theoretical value in December 2005 was PLN 2256. The average price increase was found to be $0.59 \%$ monthly. The average unit prices were characterized by a rising tendency from the beginning of the analyzed period; in the last analyzed year the average price rose by over $25 \%$ vs. 2006 and at the end of the whole analyzed period it amounted to $2256 \mathrm{PLN} / \mathrm{m}^{2}$. One half of the transactions were concluded at a higher price and the other half below $2214 \mathrm{PLN} / \mathrm{m}^{2}$.

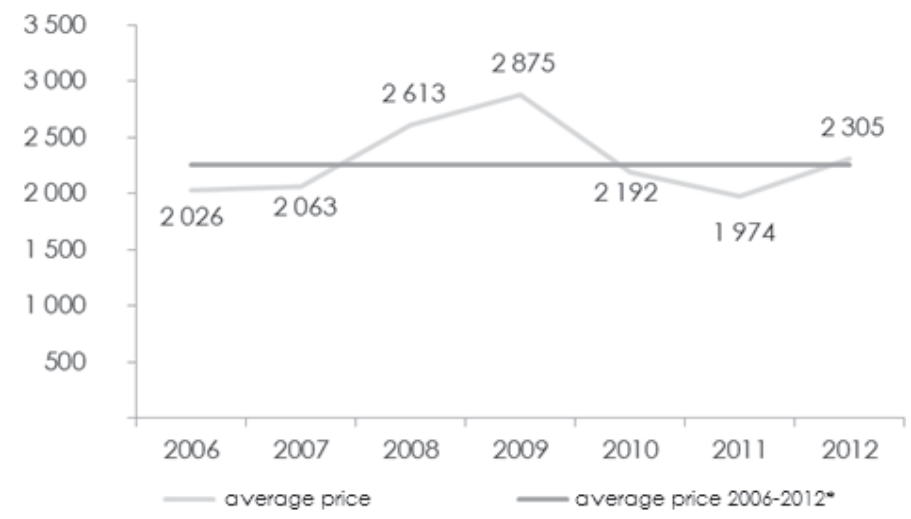

Chart 10. Average price [PLN/m2] - properties built up with residential buildings in Kalisz in 2006-2012 Source: self-study.

An analysis of average unit prices for individual area ranges shows that the highest values are reached by properties built up with buildings whose area is less than $150 \mathrm{~m}^{2}$; areas above $200 \mathrm{~m}^{2}$ cause an average reduction of unit prices of up to $15 \%$. 


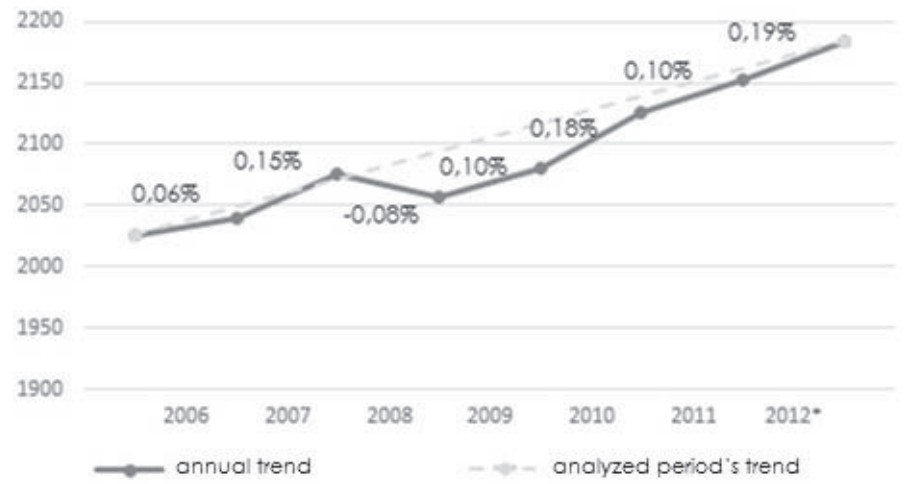

Chart 11. Price fluctuations [PLN/m2] at the market of properties built up with single-family homes in 2006-2012 in Kalisz - annual trend and the analyzed period's trend Source: self-study.

The trend lines in the above chart are marked with annual average price fluctuations in the individual analysis periods. Despite the price increase in $2006-2012$ by $7.1 \%$ annually on average, 2008 witnessed a slight price reduction $(0.9 \%$ annually). The highest price increase for residential buildings was recorded in 2010 (2.3\% annually).

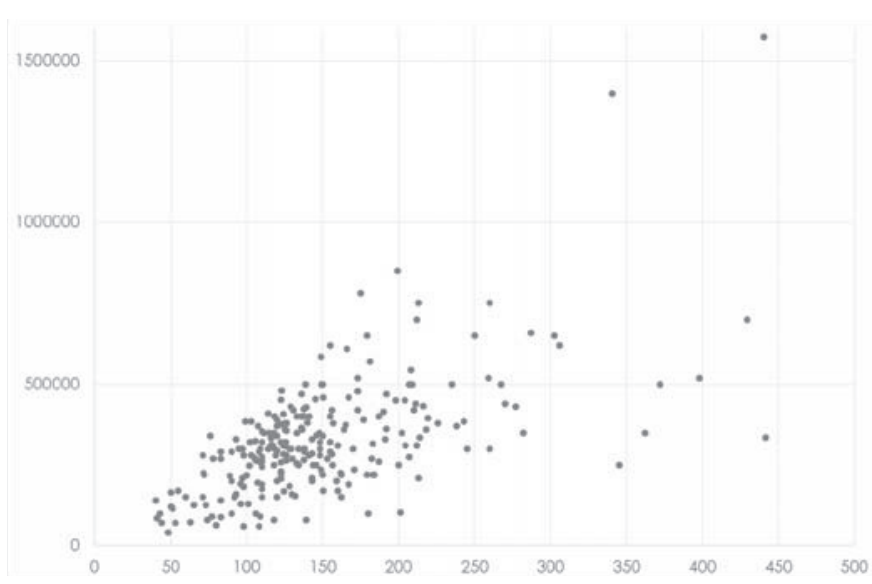

Chart 12. Dependence between the price $[\mathrm{PLN}]$ and home area $[\mathrm{m} 2]$ Source: self-study

The correlation dependence between the building's usable area and the transactional price is positive (bigger area means higher property price); prices of properties built up with residential buildings are also affected by other factors of lesser influence than the area. 


\section{CONCLUSION}

The recent years have shown that the property market in Poland is subject to the same cycles and tendencies as other markets.

The strength of the domestic market is a high unsatisfied demand for goods such as a flat: the unsatisfied demand potentially amounts to approximately 1 million flats (Nykiel, 2009). The analyzed period shows an increase of transactional prices in the residential market in Kalisz including a correction in 2009. Particularly, in 2007 significant price differences and a large number of transactions occurred when compared to the other analyzed years; they resulted from a revival in the property market in Poland, which is especially tangible in big towns. In 2008-2009 a slightly weaker activity could be seen in the residential property market. The drop in the number of transactions could be attributed to several factors: the global financial crisis which weakened investment moods, changes in banks' credit policies initiated in Q4 2008 involving more severe criteria of granting credits in connection with disturbing signal coming from international markets, reduced buying power of the potential market participants.

\section{BIBLIOGRAPHY}

Bezrobotni oraz stopa bezrobocia wg województw, podregionów i powiatów (stan w końcu grudnia 2009 r.), Główny Urząd Statystyczny, Warszawa 2009.

Bryx, M. (2006), Rynek nieruchomości. System i funkcjonowanie, Poltext, Warszawa.

Bryx, M. (2007), Uwagi o polityce mieszkaniowej w Polsce początku XXI wieku, in: Gospodarka. Inwestycje. Nieruchomości. Podatki, SGH, Warszawa.

Gawron, H. (2007), Opłacalność inwestowania na rynku nieruchomości, Wydawnictwo Akademii Ekonomicznej w Poznaniu, Poznań.

Kucharska-Stasiak, E. (2008), Nieruchomość w gospodarce rynkowej, Wydawnictwo Naukowe PWN, Warszawa.

Ludność. Stan i struktura $w$ przekroju terytorialnym. Stan w dniu 30 VI 2009 r. Główny Urząd Statystyczny, Warszawa 2009 .

Łaszek, J. (2007), Ryzyko rynku nieruchomości w Polsce z perspektywy doświadczeń na rynku USA, w: Ryzyko rynku nieruchomości, Zeszyty BRE Bank - CASE, Nr 92/2007, Warszawa.

Nykiel, L. (2008), Rynek mieszkaniowy w Polsce, Zeszyt 25/2008, Fundacja na Rzecz Kredytu Hipotecznego, Warszawa.

Obrót nieruchomościami w 2010 r., Główny Urząd Statystyczny, Warszawa, 2011.

Obrót nieruchomościami w 2011 r. Informacje i opracowania statystyczne, Główny Urząd Statystyczny, Warszawa 2012.

Poznaniak szuka małego mieszkania w bloku, Gazeta Wyborcza Poznań, 2010-04-21.

Raport: Rynek mieszkaniowy w Polsce, REAS.

Rącka, I. (2009), Czynniki wpływające na wartość nieruchomości gruntowych niezabudowanych o przeznaczeniu mieszkaniowym jednorodzinnym na podstawie analizy kaliskiego rynku nieruchomości w latach 2003-2008, Biuletyn Stowarzyszenia Rzeczoznawców Majątkowych Województwa Wielkopolskiego, Nr 3/22, SRMWW, Poznań.

Strączkowski, Ł. (2009), Motywy zakupu mieszkań w świetle badań nabywców na lokalnym rynku mieszkaniowym w Poznaniu, Studia i Materiaty Towarzystwa Naukowego Nieruchomości Nr XVII.2, Olsztyn.

Tofil, J. (2007), Rynek nieruchomości a ryzyko bankowe w: Ryzyko rynku nieruchomości, Zeszyty BRE Bank - CASE, Nr 92/2007, Warszawa.

Transakcje kupnalsprzedaży nieruchomości w 2007 r., Główny Urząd Statystyczny, Warszawa, wrzesień 2008.

Trojanek R., Dwelling's Price Fluctuations and the Business Cycle, ECONOMICS Economics \& Sociology, Vol. 3, No 2, 2010, pp. 67-77.

Trojanek, R. (2008), Wahania cen na rynku mieszkaniowym, Akademia Ekonomiczna w Poznaniu, Poznań. 